\title{
Correlation between Pesticide Exposure and Cholinesterase Level of Sprayer Workers in PT. Langkat Nusantara Kepong Gohor Lama
}

\author{
Dealita Khairani Daulay, Gerry Silaban ${ }^{2}$, Taufik Ashar ${ }^{2}$ \\ ${ }^{1}$ Master Student in Faculty of Public Health, Universitas Sumatera Utara, Medan, Indonesia \\ ${ }^{2}$ Lecturer in Faculty of Public Health, Universitas Sumatera Utara, Medan, Indonesia \\ Email: dealitadaulay8@yahoo.com
}

\begin{abstract}
:
Pesticides are toxic substances which have some negative impact on human health problems. Cholinesterase enzymes play a role in keeping the muscles, glands and nervous system working harmoniously. The high and low activity of cholinesterase enzyme is an indicator of the level of poisoning in the human body and can be used as an indication of the presence of pesticides in the blood. The purpose of this study was to analyse the relationship of pesticide exposure with cholinesterase levels in the blood of pesticide spraying workers at PT. Langkat Nusantara Kepong Gohor Lama. The research method used is Cross-Sectional at PT. Langkat Nusantara Kepong Gohor Lama with a total sample of 65 workers was obtained by Simple Random Sampling. Information was obtained through interviews with questionnaire aids and cholinesterase examination using a tintometer kit. Based on the results of the analysis using chi-square obtained exposure to pesticides associated with cholinesterase levels in the blood of pesticide sprayers. The result of this study shows that the level of cholinesterase is significantly related to the length of service $(p=0.004)$ and the use of Personal Protective Equipment (PPE) $(p=0.002)$. Suggestions for workers to be more obedient in using PPE in the workplace to minimize exposure to pesticides that enter the body, for companies to pay more attention to the feasibility of PPE that is replacing damaged PPE, make rules or sanctions if workers are negligent and do not use PPE that has been provided and workers with abnormal levels of cholinesterase should be moved temporarily to a minimum of chemical work and companies are advised to use environmentally friendly pesticides so as not to endanger workers, animals and non-targeted insects.
\end{abstract}

Keywords:

pesticide exposure; cholinesterase level; pesticide sprayer workers

\section{Introduction}

Pesticides are a means to kill plant pests. Its use is according to the rules and in the right way is an absolute thing that must be done given that pesticides are toxic materials that have the potential to have a negative impact on the environment and biodiversity, cause resistance, resurrection, the emergence of new pests, and disruption of human health and other living things, so it must be managed carefully (Ministry of Agriculture RI, 2015).

The use of pesticides has been increased, especially in developing countries, including Indonesia. Developing countries only use $25 \%$ of the total worldwide use of pesticides, but in the case of deaths due to pesticides, $99 \%$ are experienced by these countries.

According to WHO (World Health Organization), this is due to the low level of education of farmers in the country so that the method of its use tends to be unsafe or not by existing regulations. The World Health Organization (WHO) estimates that 1-5 million cases of pesticide poisoning occur annually in agricultural workers with a death rate of 220,000 . About 
$80 \%$ of pesticide poisoning is reported to occur in developing countries. In Indonesia, an estimated 300,000 cases of poisoning occur each year, although only a small proportion are fatal (Lesar, 2016).

Based on research conducted by Sularti (2012) in Mojogedang Subdistrict of Karanganyar Regency out of 45 spraying workers, 30 spraying workers experienced poisoning symptoms of $67 \%$ in the farmer group. Based on Nganchamung (2017) in Thailand reported as many as $27.8 \%$ of farmers experienced symptoms of headaches symptoms, fatigue and blurred vision for 48 hours after using pesticides and $22.2 \%$ of farmers experienced more than three symptoms including nausea or vomiting.

Pesticides can enter the body through inhalation. The examination of Cholinesterase levels in the blood of workers is carried out to determine to poison or whether the body has been exposed to pesticides. Blood Cholinesterase activity is the number of active Cholinesterase enzymes in blood plasma and red blood cells that play a role in maintaining the balance of the nervous system. Blood cholinesterase activity is used as an indicator of organophosphate pesticide poisoning (Sartono, 2002).

Annual report data at PT. Langkat Nusantara Kepong is known that in the examination of blood cholinesterase levels, the majority of pesticide spraying workers are poisoned. Based on Anggraini's Research (2015) at PT. Langkat Nusantara Kepong Kebun Tanjung Keliling spraying pesticide workers who have a severe poisoning rate of $75 \%$ with symptoms such as nausea, chills, difficulty breathing and increased pulse rate.

Based on the results of an initial survey at PT Langkat Nusantara Kepong Kebun Gohor Lama Langkat Regency pesticide spraying workers spraying at 08.00 am to 13.00 noon. According to Risnawati (2017), the time for workers to do the spraying is 8:00 a.m. to 11:00. The spraying time is a maximum of 3-4 hours. The safe temperature for spraying is $240 \mathrm{C}-300$ C. Exceeding temperatures will make workers easy to sweat so the pores will open and pesticides will quickly enter through the skin. In the survey it was also seen that the irregular direction of spraying technique, this would facilitate the exposure of pesticides into the body of workers due to direct contact with pesticides. According to Isnawan (2013) the direction of spraying which is opposite to the direction of the wind will provide more exposure so that it is more susceptible to poisoning. The absorption of these pesticides will be more optimal if workers do not use complete personal protective equipment.

The purpose of this study was to analyse the relationship between pesticide exposure and cholinesterase levels in pesticide sprayers at PT. Langkat Nusantara Kepong Kebun Gohor Lama in 2018 .

\section{Research Method}

This research is a quantitative observational analytic study using a cross-sectional design. This research was conducted at PT. Langkat Nusantara Kepong Kebun Gohor Lama, Langkat Regency, North Sumatra. The population of this study was 90 workers. The sample used was 65 workers with a simple random sampling technique. The results of blood tests will be known the level of poisoning by these pesticides, namely: Normal category, if $>75 \%-100 \%$, mild poisoning category, if $>50 \%-75 \%$, moderate poisoning category if $>25 \%-50 \%$ category of severe poisoning, i.e. if $0 \%-25 \%$ (Ministry of Health RI, 1992). 
Some of the tools and materials used are questionnaire aids to determine the length of service, the use of PPE, personal hygiene and Tintometer kits to determine the level of cholinesterase. There are 2 data analysis in this study, namely, univariate and bivariate analysis.

\section{Result and Discussion}

PT. Langkat Nusantara Kepong is a private company that has 8 garden and 1 MCC (mills). The total area of approximately 21,000 hectares of oil palm plantations. The company is located in the village of Old Gohor, Langkat and employed about 355 people, including 90 workers and 5 foreman garden. The area of 3,050 hectares of oil palm is divided into five divisions, and each division is overseen by one person foreman. Pesticides are used by workers are Becano, Cyprien, Dejavu, Fascinate, Ingrofol, Kenlon, Konup, Metaprima, Pastifat, Vondozeb, Prima Up, and Kenfosat, a herbicide for control of shrubs, weeds woody, broadleaf weeds and broadleaf weeds narrow.

Table 1. Frequency Distribution of Total Exposure to pesticides on workers at PT. Langkat Nusantara Kepong

\begin{tabular}{llc}
\hline Variables & $\mathrm{N}$ & $\%$ \\
\hline Years of service & 38 & 58.5 \\
$>5$ Years & 27 & 41.5 \\
= <5 Years & 65 & 100 \\
amount & & \\
Personal Hygiene & 38 & 58.5 \\
Not good & 27 & 41.5 \\
Well & 65 & 100 \\
amount & & \\
The use of PPE & 28 & 43.1 \\
Not obey & 37 & 56.9 \\
submissive & 65 & 100 \\
amount & & \\
cholinesterase levels & 32 & 49.2 \\
Abnormal & 33 & 50.8 \\
Normal & 65 & 100 \\
amount & & \\
\hline
\end{tabular}

The results were obtained blood samples from workers with tenure $>5$ years were 38 workers $(58.5 \%)$ and tenure $=<5$ years $27(41.5 \%)$ workers. Personal hygiene on the obtained results from unfavourable workers in personal hygiene as many as 38 workers (58.1\%) and good personal hygiene in a total of 27 workers $(41.5 \%)$. On the use of PPE got the result that workers who do not comply by 28 workers (43.1\%) and obedient in the use of PPE as many as 37 workers $(56.9 \%)$, and workers with high levels of cholinesterase not average total of 32 workers $(49.2 \%)$ and workers with higher levels of cholinesterase average total of 33 workers $(50.8 \%)$.

Table 2. Relationship with Pesticide Exposure Levels of cholinesterase On Worker Pesticide Sprayers

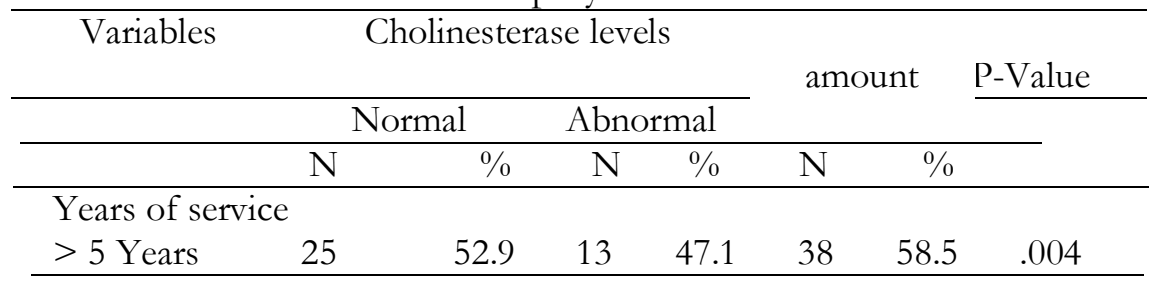




\begin{tabular}{|c|c|c|c|c|c|c|c|}
\hline$=<5$ Years & 8 & 29.6 & 19 & 70.1 & 27 & 41.5 & \\
\hline amount & 33 & 50.8 & 32 & 49.2 & 65 & 100 & \\
\hline \multicolumn{8}{|c|}{ The use of PPE } \\
\hline Not obey & 8 & 28.6 & 20 & 71.4 & 28 & 43.1 & .00 \\
\hline submissive & 25 & 67.6 & 12 & 32.4 & 37 & 58.9 & \\
\hline amount & 33 & 50.8 & 32 & 49.2 & 65 & 100 & \\
\hline
\end{tabular}

The tenure of the contribution to be the cause of poisoning in workers spraying pesticides. Pesticide sprayers. Pesticide spraying workers with tenure of more than 5 years will have a higher risk for poisoning. The study shows that 13 workers [spraying of pesticides $(49.2 \%)$ who have worked for more than 5 years cholinesterase which possessed normal levels.

The study shows that there is a relationship between the work period ( $p$-value $=0.004)$, and the use of PPE ( $\mathrm{p}$-value $=0.002)$ associated with pesticide poisoning in the sprayers. The use of PPE non-compliance also have contributed to the occurrence of toxicity in the sprayers in PT Langkat Nusantara Kepong Lama Gohor which can be seen in the table above $71.4 \%$ of workers who do not abide in the use of PPE has cholinesterase levels are not healthy.

The working period is the time that is calculated based on the first year of research work to date measured in years, years have contributed to a decrease in cholinesterase levels, workers with long working lives have a higher risk to be exposed to pesticide poisoning. the longer the worker becomes sprayers, contact with pesticides would be even higher, and the risk of pesticide poisoning would be even higher. The longer the exposure to pesticides which will lead poisoning due to exposure to pesticides so that the number of toxins will accumulate in the body tissues and affect the health of workers.

This study is in line with research Osang (2016) on a rice farmer in the village Pangian Mongondow district that shows their relationship with the working lives of pesticide poisoning in the sprayers with $\mathrm{p}$-value of $0.000(\mathrm{p}<0.05)$ and Rustia et al. (2010) explains that long work more than 3 years in handling pesticides tend to get exposed to higher risk than the farmers who experienced less than 3 years, it is caused by prolonged contact with pesticides over the years.

Some farmers spray at 08:00 to 11:00 am, because of the location of the current study began at $12.00 \mathrm{pm}$ tends to rain. Spraying time associated with ambient temperatures can cause perspiration more, especially during the day, so it's more natural poisoning absorption through the skin.

This study shows about the usage of PPE in line with research Achmadi (2014), said that the information about the body part most exposed to risks as a sign of poisoning, and protective clothing should be used. Parts of the body that are susceptible to pesticide users using spray equipment is the hands and chest, while the more closed parts of the body of the health effects of pesticide use in the work can be reduced.

And research conducted by Kurniasih (2013), argued that the use of PPE when spraying affect the amount of grain pest entry of farmers into the body. In this study, there is a relationship between the uses of Personal Protective Equipment (PPE) with cholinesterase levels. The use of PPE when spraying is very influential on the number of entry of pesticides in the body of farmers. The use of PPE should be appropriate procedures according to Agricultural Research (2014), farmers should use hats, goggles, masks, gowns, latex gloves, long pants, and sneakers. If the farmer wearing full PPE will be able to reduce and minimize exposure to pesticides can lead to human health problems. 


\section{Conclusion}

Based on research conducted on 65 samples of sprayer workers in PT. Langkat Nusantara Kepong Lama Gohor found that there are still many workers who do not abide in the use of PPE and does well in personal hygiene. From the results, we know to tenure, and use of PPE has been associated with toxicity in the sprayers in pt langkat Nusantara Kepong Lama Gohor.

It is expected to be more docile workers in using the PPE at the workplace to minimize exposure to pesticides that enter into the worker's body, such as using a hat or helmet, mask types chemical Cartridge, Long-sleeved shirt, long pants, aprons, goggles and boots. Meanwhile the company more attention to the feasibility of PPE is replacing PPE is damaged, make rules or sanctions if workers are negligent and do not use PPE provided and workers with high levels of cholinesterase were not average should be moved temporarily to a job that minimal chemicals and companies are advised using environmentally friendly pesticides that do not harm workers, non-target animals and insects. Further research is needed on toxicity using other variables that may act as an essential risk factor and unknown.

\section{References}

Achmadi, Umar Fahmi., 2014. Based on Disease Management Areas, Jakarta: King Grafindo Persada.

Afriyanto., 2008. Study on Farmer Spraying Pesticide Poisoning Cabe In the village temple Bandungan District of Semarang District. Thesis. UNDIP.

Djau, Rusli Asri., 2009. Genesis Anemia And Risk Factors Pesticide Poisoning In Sprayers Full Weeds Palm Plantation PT. Agro Indomas Kab. Seruyan Central Kalimantan. Thesis. UNDIP.

Isnawan, Reni Mamang., 2013. Factors Associated With Pesticide Poisoning incident At Red Onion Growers Kedunguter In the village of Brebes Brebes District. Journal of Public Health. 2 (1), 1-11.

Kurniasih, Aisha., Setiani, Onny., Nugraheni, Sri Achadi., 2013. Factors Related to Exposure to Pesticides and Their Relation to Genesis Anemia in Horticulture Farmers in the village Gombong Belik District of Pemalang in Central Java. Journal of Environmental Health of Indonesia. 12 (2). 132-137.

Kurniawan, Anggoro., 2009. The relationship between the use of Personal Protective Equipment (PPE) With Pesticide Poisoning Genesis Growers Sprinkler In Hama In the village Ngrapah Banyubiru District of Semarang District 2008. Thesis. UNES.

In January, the District reports Juhar., 2018.

National Report Basic Health Research (Riskesdas), 2007.

Lesar, FY Joseph, WB and Rattu, AJM, 2016.Relationship Between Education And Awareness Level of Pesticide Hazards to Your Health With Pesticide Management At Farmers Group In District Belang Southeast Minahasa Regency.Ejournalhealth. 1 (5) Faculty of Public Health, University of Sam RatulangiVol 1, No. 5 (2016),

Agricultural Research., 2014, Pesticide Spraying Techniques (Horticulture Research and Development Center).

Maksuk., Andiani, lady., Suzanna., Amin, Maliha., 2017. Analysis of Risk Factors Genesis Anemia In Herbicide Applicator (Case Study On Oil Palm Pt. S Banyuasin). Journal of Public Health. 8 (1). 35-43.

Minaka, Dwi Astuti., Savitri, AAS, Wirawan, DN, 2016. Relations Pesticides and protective equipment with Health Complaints In Horticulture Farmers in Buleleng. Public Health and Preventive Medicine Archive. 4 (1). 94-103. 
Nganchamung, T. Robson, MG and Siriwong, W. 2017.Association Between Blood Cholinesterase Activity, Hands-On Organophosphate Pesticide residues, Chile And Health Effects Among Farmers In Ubon Ratchathani Province, Northeastern Thailand, 68 (2): 175-183.

Prasetyaningsih, Yuliana., Desto, Arisandi., Retnosetiawati, Puri Dwi., 2017. The percentage of Genesis Anemia In Farmers Exposed to Pesticides in Farmers Group Karang Rejo, Krinjing Lor village, Village Jatisarono, District Nanggulan, Kulon Progo. 18 (2), 452-457.

Sularti and Abi Muhlisin. 2012. Knowledge Level Pesticide Hazards and PPE Usage Habits Seen From The emergence of Poisoning Signs On Farmers Group in Karanganyar. Journals. Faculty of Health Sciences. Muhammadiyah Surakarta University. Semarang https://publikasiilmiah.ums.ac.id/bitstream/handle/ Accessed on April 8, 2015.

Osang, AR, Lampus, BS and Wuntu, AD 2016. The relationship between past crimes and wind direction with blood cholinesterase levels on rice farmers in the village of pesticide users pangian middle eastern sub-district Bolaang Mongondow District passions. Pharmaceutical scientific journal. Faculty of Sam Ratulangi University public health. Manado. Vol 5 No 22016 